Article

\title{
Theoretical Analysis on Heteroleptic Cu(I)-Based Complexes for Dye-Sensitized Solar Cells: Effect of Anchors on Electronic Structure, Spectrum, Excitation, and Intramolecular and Interfacial Electron Transfer
}

\author{
Zhijie $\mathrm{Xu}{ }^{1, *}$, Xiaoqing $\mathrm{Lu}^{2, *}$, Yuanyuan $\mathrm{Li}^{1}$ and Shuxian Wei ${ }^{1, *}$ \\ 1 College of Science, China University of Petroleum, Qingdao 266580, China; yylzjx@163.com \\ 2 School of Materials Science and Engineering, China University of Petroleum, Qingdao 266580, China \\ * Correspondence: xuzj@upc.edu.cn (Z.X.); luxq@upc.edu.cn (X.L.); wshx@upc.edu.cn (S.W.); \\ Tel.: +86-532-8698-3376 (Z.X.); +86-532-8698-3415 (X.L.); +86-532-8698-3410 (S.W.)
}

Academic Editors: Claudia Dragonetti and Ladislav Kavan

Received: 4 July 2020; Accepted: 11 August 2020; Published: 12 August 2020

\begin{abstract}
Two groups of heteroleptic $\mathrm{Cu}(\mathrm{I})$-based dyes were designed and theoretically investigated by density functional theory (DFT) and time-dependent DFT (TD-DFT) methods. Different anchors were integrated into the dye skeleton to shed light on how the type of anchor influenced the electronic structure, absorption spectrum, electron excitation, and intramolecular and interfacial electron transfer of dyes. The results indicated that, compared with other dyes, the dyes with cyanoacrylic acid and nitric acid exhibited more appropriate electron distributions in frontier molecular orbitals (FMOs), lower HOMO (the highest occupied molecular orbital) -LUMO (the lowest unoccupied molecular orbital) energy gaps, broader absorption spectral ranges as well as improved spectral characteristics in the near-infrared region and better intramolecular electron transfer (IET) characteristics with more electrons transferred to longer distances, but smaller orbital overlap. Among all the studied $\mathrm{Cu}(\mathrm{I})$-based dyes, B1 and P1 (with cyanoacrylic acid anchoring group) exhibited the best interface electronic structure parameters with a relatively short electron injection time $\left(\tau_{\text {inj }}\right)$ and large dipole moment $\left(\mu_{\text {normal }}\right)$, which would have a positive effect on the open-circuit photovoltage $\left(V_{\text {oc }}\right)$ and short-circuit current density $\left(\mathrm{J}_{\mathrm{sc}}\right)$, resulting in high power conversion efficiency (PCE) of dye-sensitized solar cells (DSSCs). Our findings are expected to provide a new insight into the designing and screening of high-performance dyes for DSSCs.
\end{abstract}

Keywords: dye-sensitized solar cells (DSSCs); $\mathrm{Cu}(\mathrm{I})$-based complex; anchor; density functional theory (DFT)

\section{Introduction}

Dye-sensitized solar cells (DSSCs), as a promising photovoltaic device, with advantages of relatively high efficiency and low-cost fabrication, have gained widespread attention since $\mathrm{Ru}$ (II) polypyridyl complexes were first reported and their excellent power conversion efficiency (PCE) was demonstrated in 1991 by Grätzel and co-workers [1]. Since then, lots of significant progress has been made in $\mathrm{Ru}$ (II) polypyridyl complex-based DSSCs, with PCE up to $11.5 \%$ [2-9]; however, the rarity and high cost of ruthenium limited the large-scale utilization of Ru(II)-based dyes in DSSC application. Therefore, it is necessary to develop novel dyes with plentiful and cheap components as other replacements. Copper, as an abundant and nontoxic, non-noble metal, might be a good substitute for ruthenium in DSSCs. Sauvage and co-workers first introduced heteroleptic $\mathrm{Cu}(\mathrm{I})$-polypyridine complexes in DSSCs in 1994 [10]. Furthermore, it was reported that $\mathrm{Cu}(\mathrm{I})$-based complexes could be efficient dyes due to their adequate electron transfer capacities in DSSCs [11,12]. In recent years, 
many molecular engineering strategies were applied in $\mathrm{Cu}(\mathrm{I})$-based complexes for DSSC application and impressive photoconversion efficiencies were obtained. In 2008, Constable and co-workers reported that 6,6'-disubstituted-2,2'-bipyridine-based $\mathrm{Cu}(\mathrm{I})$ complexes with carboxylic acid as the anchoring group can be used as effective sensitizers for $\mathrm{TiO}_{2}$ and surprisingly resulted in high PCE of $2.3 \%$ [13]. A few years later, PCE of Cu(I) complex-based DSSCs was further increased to $2.89 \%$ by using phosphonic acid as the anchoring group [14]. It is worth mentioning that Sandroni and co-workers enhanced the PCE of $\mathrm{Cu}(\mathrm{I})$ complex-based DSSCs to $4.66 \%$ by utilizing heteroleptic Cu(I)-based complexes combined with carboxylic acid anchoring group [15]. At present, although the PCE of $\mathrm{Cu}(\mathrm{I})$-based DSSCs is still far behind that of $\mathrm{Ru}(\mathrm{II})$ polypyridyl complexes, it has exhibited great potential in DSSC application, and there is much room to improve the PCE of Cu(I)-based DSSCs.

In recent years, our group was devoted to the molecular design and related theoretical research of $\mathrm{Cu}(\mathrm{I})$-based complexes for DSSCs [16-19], and a series of heteroleptic Cu(I)-based complexes with functionalized chromophores, ligands, and acceptors were investigated by the density functional theory (DFT)/time-dependent DFT (TD-DFT) approach. Furthermore, some meaningful conclusions about the internal mechanism of the effects of functional groups on the optoelectronic properties of $\mathrm{Cu}(\mathrm{I})$-based dyes have been obtained. In addition, it is well-known that a stable sensitizer should possess an anchoring group in its molecular structure, which allows the attachment of the dye to the $\mathrm{TiO}_{2}$ surface. The anchoring group plays an important role in high PCE of DSSCs. However, to the best of our knowledge, only a few studies were focused on the screening and tuning of the anchoring groups to elucidate their effects on photon-to-electron performance of $\mathrm{Cu}(\mathrm{I})$-based dyes. It is essential to enrich the research field of $\mathrm{Cu}(\mathrm{I})$-based dyes and gain more information on the structure-property relationships, as a further step in promoting copper(I)-based complexes to effectively replace ruthenium(II) complexes in DSSCs. In this study, two groups of heteroleptic Cu(I)-based dyes, B1-B5 and P1-P5, with different anchoring groups (selected from cyanoacrylic acid, carboxylic acid, nitric acid, phosphonic acid, and sulfonic acid) in bipyridine (bpy)/2,9-dimethyl-1,10-phenanthroline (dmp) ligand were designed. The intrinsic properties, such as the electronic structure, absorption spectrum, electron excitation, and intramolecular and interfacial electron transfer, of the designed $\mathrm{Cu}(\mathrm{I})$-based dyes were theoretically investigated by DFT and TD-DFT methods. This work aimed to shed light on how the type of anchor influenced the photoelectric properties of $\mathrm{Cu}(\mathrm{I})$-based dyes for DSSC applications. Results of this work would provide a deep insight into the intrinsic mechanisms for the design and screening of high-performance $\mathrm{Cu}(\mathrm{I})$-based dyes in DSSCs.

\section{Computational Method}

In this work, unless otherwise stated, all the DFT/TD-DFT calculations were performed with the Gaussian 09 program package [20]. The ground-state geometries of all the studied $\mathrm{Cu}(\mathrm{I})$-based dyes were optimized by the B3LYP (Becke 3 parameter exchange functional with correlation functional by Lee, Yang and Parr) [21,22] exchange-correlation functional in conjunction with a mixed DZVP (double-zeta valence polarized)/6-31G(d) [23,24] basis set in DCM (dichloromethane) solvent. In this mixed basis set, the 6-31G(d) basis set was chosen for non-metal atoms, and the DZVP set supplemented with three sets of uncontracted pure angular momentum $f$ functions was chosen for the $\mathrm{Cu}$ atom. To confirm the stationary of all the optimized geometries, vibrational analyses were also performed at the same level. The results showed that all the optimized structures corresponded to a minimum of potential energy surface with no imaginary frequency. Based on the optimized ground-state structures, electronic excitation and absorption spectra were calculated using the TD-DFT method with the 6-31G(d) basis set for C, H, O, N, and S atoms and DZVP for Cu atoms, in DCM solvent. The obtained TD-DFT results were further submitted to Multiwfn [25] to obtain the absorption spectra. In addition, the electron density differences were also calculated with Multiwfn by comparing the charge density in the ground state and excited state of the dyes. Furthermore, electron transfer parameters, including the distance of electron transfer $\left(\mathrm{d}^{\mathrm{ET}}\right)$, transferred charge $\left(\mathrm{q}^{\mathrm{ET}}\right), H$, and $t(H$ is the half of the sum of 
centroid axis along the electron transfer direction and $t$ is the difference between $\mathrm{d}^{\mathrm{ET}}$ and $H$ ) index were calculated with Multiwfn [25].

The solvent effect was evaluated by using the non-equilibrium implementation of the conductor-like polarizable continuum model (C-PCM) [26]. In particular, the optimized structure and solvation energy were computed by a cavity model [27] coupled to C-PCM. This approach provided results very close to those obtained by the original dielectric model for high dielectric constant solvents and thus was more efficient in geometry optimization and less prone to make numerical errors arising from the small part of the solute electron cloud lying outside the cavity [28].

For the calculation results to be close to the experimental results, calculation method calibrations were performed to find a suitable level for the excited state description of the studied $\mathrm{Cu}(\mathrm{I})$-based dyes. Different levels of TD-DFT methods were adopted to calculate the absorption spectra of $\left[\mathrm{Cu}\left(\mathrm{bpy}(\mathrm{Mes})_{2}\right)(\mathrm{phen})\right] \mathrm{BF} 4$ and $\left[\mathrm{Cu}\left(\mathrm{bpy}(\mathrm{Mes})_{2}\right)(\mathrm{dmp})\right] \mathrm{BF} 4$ in DCM solution. The calculation results, together with the experimental data, are listed in Table S1 (Supplementary Materials) and plotted in Figure S1 (Supplementary Materials). As shown in Figure S1, the lowest absorption peaks were located at $476 \mathrm{~nm}$ (phen (1,10-phenanthroline)-based dyes) and $477 \mathrm{~nm}$ (dmp (2,9-dimethyl-1,10-phenanthroline)-based dyes) at the B3LYP/DZVP level, which were very close to the experimental data (476 nm and $463 \mathrm{~nm}$, respectively) [29]. At the B3LYP/LanL2DZ level, both values were $450 \mathrm{~nm}$ for phen-based dyes and $449 \mathrm{~nm}$ for dmp-based dyes. At the B3LYP/6-31G(d) level, both values were $540 \mathrm{~nm}$ for phen-based dyes and $549 \mathrm{~nm}$ for dmp-based dyes, which blue-shifted severely compared with the benchmark. Comparatively, the results obtained with B3LYP/DZVP level matched better with the benchmark than those with B3LYP/LanL2DZ and B3LYP/6-31G(d) levels. Therefore, all the TD-DFT calculations were performed at the B3LYP/DZVP level unless otherwise stated.

\section{Results and Discussions}

\subsection{Molecular Geometry}

In 2009, Chen and co-workers reported the synthesis of the Ru(II)-based dye CYC-B11 by incorporating thiophene derivatives into the ancillary ligand [30], which exhibited a high PCE of $11.5 \%$. By referring to the CYC-B11 structure, in this study, two groups of heteroleptic $\mathrm{Cu}(\mathrm{I})$-based dyes, B1 B5 (group I) and P1 P5 (group II), with different anchoring groups (selected from cyanoacrylic acid, carboxylic acid, nitric acid, phosphonic acid, and sulfonic acid) in bipyridine (bpy)/2,9-dimethyl-1,10-phenanthroline ( $\mathrm{dmp}$ ) ligand were designed. The structures of the designed $\mathrm{Cu}(\mathrm{I})$-based dyes are shown in Figure 1.
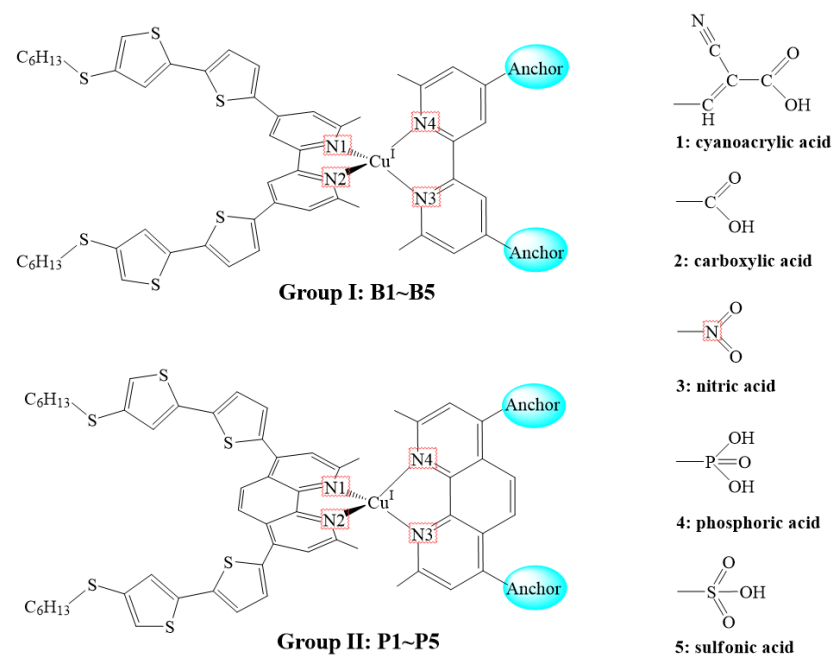

Figure 1. Molecular structures of B1-B5 and P1-P5. 
The structural parameters of $\mathrm{Cu}(\mathrm{I})$-based dyes are listed in Table 1. For all the studied dyes, the bond lengths $R_{\mathrm{Cu}-\mathrm{N} 1}$ and $\mathrm{R}_{\mathrm{Cu}-\mathrm{N} 2}$ were in the range of 2.056-2.068 $\AA$, while $\mathrm{R}_{\mathrm{Cu}-\mathrm{N} 3}$ and $\mathrm{R}_{\mathrm{Cu}-\mathrm{N} 4}$ were in the range of 2.070-2.081 $\AA$. The bite angles of $\angle \mathrm{N} 1-\mathrm{Cu}-\mathrm{N} 2$ and $\angle \mathrm{N} 3-\mathrm{Cu}-\mathrm{N} 4$ fluctuated within $79.9-81.1^{\circ}$, while $\angle \mathrm{N} 2-\mathrm{Cu}-\mathrm{N} 3$ and $\angle \mathrm{N} 2-\mathrm{Cu}-\mathrm{N} 4$ fluctuated within $124.7-126.3^{\circ}$. The small fluctuations of bond length and bite angle indicated that the anchoring groups had a slight effect on the geometry structure of $\mathrm{Cu}(\mathrm{I})$-based dyes. The $\mathrm{R}_{\mathrm{Cu}-\mathrm{N} 3}$ and $\mathrm{R}_{\mathrm{Cu}-\mathrm{N} 4}$ were obviously longer than $\mathrm{R}_{\mathrm{Cu}-\mathrm{N} 1}$ and $\mathrm{R}_{\mathrm{Cu}-\mathrm{N} 2}$, which indicated that the interactions between $\mathrm{Cu}(\mathrm{I})$ center and the anchoring group ligands were weaker than those between $\mathrm{Cu}(\mathrm{I})$ center and ancillary ligands. The geometry index $\left(\tau_{4}\right)$ [31] is usually used to describe the four-coordinate geometry of $\mathrm{Cu}(\mathrm{I})$-based dyes. Herein, the $\tau_{4}$ is described as

$$
\tau_{4}=\left\{360^{\circ}-(\theta+\varphi)\right\} / 141^{\circ}
$$

where $\theta$ and $\varphi$ are the two largest angles in the four-coordinate geometry. The $\tau_{4}$ value is 1.00 for a perfect tetrahedron (largest angles of $109.5^{\circ}$ ), 0 for square planar (largest angles of $180^{\circ}$ ), and 0.85 for a perfect trigonal pyramid (largest angles of $120^{\circ}$ ); and intermediate geometries fall in the range of $0-1.00$. As shown in Table 1, the values of $\tau_{4}$ fluctuated from 0.769 to 0.772 in group I and from 0.771 to 0.773 in group II. These results indicated that all the $\mathrm{Cu}(\mathrm{I})$-based dyes exhibited the distorted trigonal pyramidal geometries, which were consistent with the previous studies [29]. The tiny differences of $\tau_{4}$ resulted mainly from the slight skeleton distortions of bpy and dmp ligands due to the connection of different anchoring groups.

Table 1. Calculated geometrical parameters of $\mathrm{Cu}(\mathrm{I})$-based dyes at the B3LYP/DZVP level in DCM solution.

\begin{tabular}{ccccccccccc}
\hline Parameters $^{1}$ & B1 & B2 & B3 & B4 & B5 & P1 & P2 & P3 & P4 & P5 \\
\hline $\mathrm{R}_{\mathrm{Cu}-\mathrm{N} 1}$ & 2.060 & 2.063 & 2.057 & 2.064 & 2.059 & 2.066 & 2.067 & 2.062 & 2.068 & 2.064 \\
$\mathrm{R}_{\mathrm{Cu}-\mathrm{N} 2}$ & 2.059 & 2.063 & 2.056 & 2.064 & 2.059 & 2.066 & 2.067 & 2.062 & 2.068 & 2.064 \\
$\mathrm{R}_{\mathrm{Cu}-\mathrm{N} 3}$ & 2.070 & 2.074 & 2.075 & 2.076 & 2.079 & 2.076 & 2.074 & 2.077 & 2.079 & 2.081 \\
$\mathrm{R}_{\mathrm{Cu}-\mathrm{N} 4}$ & 2.072 & 2.075 & 2.077 & 2.076 & 2.078 & 2.077 & 2.074 & 2.078 & 2.078 & 2.081 \\
$\angle \mathrm{N} 1-\mathrm{Cu}-\mathrm{N} 2$ & 80.8 & 80.6 & 81.0 & 80.6 & 80.9 & 80.9 & 80.8 & 81.1 & 80.8 & 81.0 \\
$\angle \mathrm{N} 2-\mathrm{Cu}-\mathrm{N} 3$ & 125.6 & 125.6 & 125.7 & 125.6 & 125.8 & 125.3 & 125.3 & 126.2 & 126.0 & 126.3 \\
$\angle \mathrm{N} 3-\mathrm{Cu}-\mathrm{N} 4$ & 80.0 & 80.2 & 80.0 & 80.0 & 79.9 & 80.4 & 80.1 & 80.0 & 80.4 & 80.2 \\
$\angle \mathrm{N} 2-\mathrm{Cu}-\mathrm{N} 4$ & 126.0 & 125.6 & 125.6 & 125.8 & 125.7 & 126.0 & 126.0 & 124.9 & 125.2 & 124.7 \\
$\angle \mathrm{N} 1-\mathrm{N} 2-\mathrm{N} 3-\mathrm{N} 4$ & 80.9 & 81.2 & 81.2 & 81.3 & 81.4 & 80.4 & 80.7 & 82.3 & 82.1 & 82.4 \\
$\tau_{4}$ & 0.769 & 0.772 & 0.771 & 0.770 & 0.770 & 0.771 & 0.771 & 0.772 & 0.772 & 0.773 \\
\hline
\end{tabular}

${ }^{1}$ Bond lengths are in angstroms and angles are in degrees.

\subsection{Molecular Orbital and Electronic Structure}

In DSSCs, the important electronic excitations usually occur from the highest occupied molecular orbitals (HOMOs) to the lowest unoccupied molecular orbitals (LUMOs), which significantly determine the charge-separated state of the dye. As shown in Figure 2, considering the similarity of the molecular orbital shapes, only molecular orbital plots of B1, B4, P1, and P4 were selected to discuss the frontier molecular orbital (FMO) distribution of the studied $\mathrm{Cu}(\mathrm{I})$-based dyes. The FMO plots of the other dyes are shown in Figure S2 (Supplementary Materials). As can be seen from Figure 2 and Figure S2, all the $\mathrm{Cu}(\mathrm{I})$-based dyes exhibited similar electron distributions on HOMOs: HOMO-2 was mainly localized at the $\mathrm{Cu}(\mathrm{I})$ center; HOMO- 1 and HOMO were contributed mainly from donor subunits and only a minor percentage from the $\mathrm{Cu}(\mathrm{I})$ center. However, the electron distributions on LUMOs of $\mathrm{Cu}(\mathrm{I})$-based dyes were diverse owing to the introduction of different anchoring groups and ligands. As shown in Figure 2 and Figure S2, for B1/P1 (with cyanoacrylic acid anchoring group), B2/P2 (with carboxylic acid anchoring group), and B3/P3 (with nitric anchoring group), the LUMO was located at the bpy/dmp moiety and anchoring group. For B4/P4 (with phosphoric anchoring group) and B5/P5 (with sulfonic anchoring group), the LUMO had fewer distribution in the anchoring group and was mainly located at the bpy/dmp moiety, which was unbeneficial for electron injection from the 
dye to the conduction band of the semiconductor. In addition, the LUMO+1 of dyes B2, B4, and B5 in group I, whose skeleton were based on bpy ligand, was delocalized over the $\mathrm{Cu}(\mathrm{I})$ center and donor subunits, manifesting that no efficient charge-separated state formed in these dyes and thus resulting in severe electron recombination. It is well-known that anchors play the role of adsorbing dyes onto the $\mathrm{TiO}_{2}$ semiconductor, so large contributions from the anchoring groups to LUMOs are valid for electron injection from dye to the conduct band of the semiconductor and can enhance the intramolecular electron transfer (IET) rate. Therefore, from the above analysis, it was not difficult to conclude that dyes with cyanoacrylic acid and nitric acid as anchoring groups exhibited more suitable FMO distribution than those with carboxylic acid, phosphoric acid, and sulfonic acid anchoring groups. In addition, compared with group I dyes (with bpy ligand), dyes with dmp ligand may exhibit a more efficient charge-separated state.

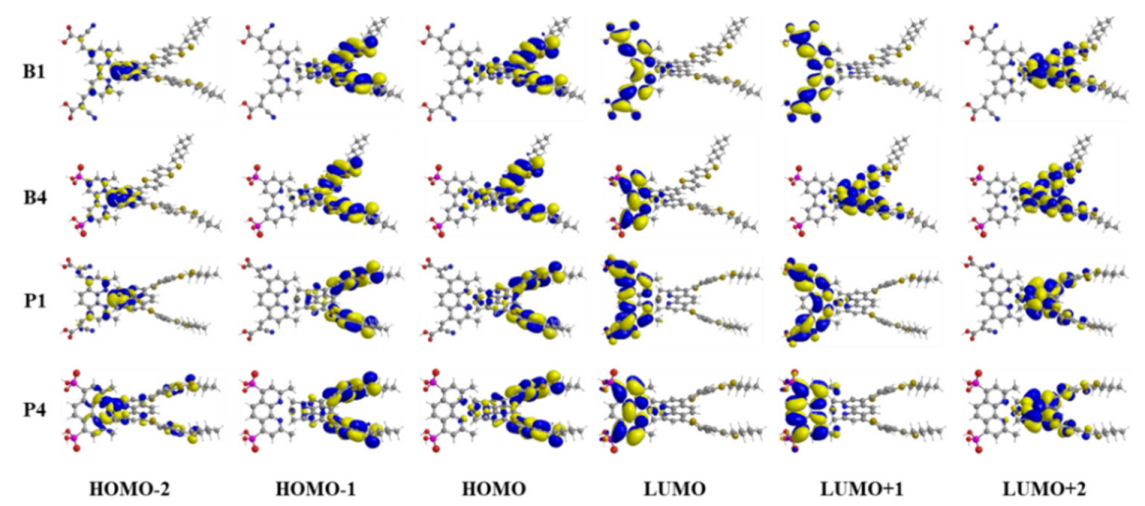

Figure 2. The frontier molecular orbitals from HOMO-2 to LUMO+2 of B1, B4, P1, and P4.

Furthermore, the energy levels of the frontier molecular orbitals from HOMO-5 to LUMO+5 and the HOMO-LUMO energy gaps of all the investigated $\mathrm{Cu}(\mathrm{I})$-based dyes are depicted in Figure 3. As shown in Figure 3, the introduction of different anchoring groups in the molecule skeleton had a slight effect on the HOMO energy, which can be rationally understood that there were the same electron donors in the two groups of dyes. However, the LOMO levels are very sensitive to the anchoring groups. Therefore, the HOMO-LUMO energy gaps of the designed dyes can be modulated by introduction of different anchoring groups. The HOMO-LUMO energy gaps of group I fluctuated in the range of 1.93-2.78 eV, while the gaps of group II fluctuated in the range of 1.94-2.76 eV. In group I, dyes B1 (with cyanoacrylic acid anchoring group) and B3 (with nitric acid anchoring group) exhibited small HOMO-LUMO energy gaps of $1.94 \mathrm{eV}$ and $1.93 \mathrm{eV}$, respectively, while B4 (with phosphoric acid anchoring group) showed the maximal gap of $2.78 \mathrm{eV}$. A similar trend was observed in group II with small HOMO-LUMO energy gaps of $2.03 \mathrm{eV}$ (P1, with cyanoacrylic acid anchoring group) and $1.94 \mathrm{eV}$ (P3, with nitric acid anchoring group). The results indicated that introduction of cyanoacrylic acid and nitric acid as anchoring groups in $\mathrm{Cu}(\mathrm{I})$-based dyes could efficiently decrease HOMO-LUMO energy gaps, which would be favorable for improving the light-harvesting ability of the dyes. These will be further verified in the following discussions about absorption spectrum.

\subsection{Absorption Spectrum and Electronic Excitation}

In order to investigate the light-harvesting abilities of the studied $\mathrm{Cu}(\mathrm{I})$-based dyes, the absorption spectra of designed dyes were calculated and are displayed in Figure 4; and the related lowest excitation state parameters are listed in Table S2 (Supplementary Materials). As shown in Figure 4, all the studied $\mathrm{Cu}(\mathrm{I})$-based dyes exhibited a similar optical absorption behavior with a short wavelength band of 260-400 nm and a long wavelength band of 400-700 nm. For the absorption peak ranges within 260-400 nm, except for P2 which showed the largest molar absorption coefficient $(\varepsilon(\lambda))$, dyes in group II showed generally identical positions and intensities; while dyes in group I, which obviously had red-shift and smaller $\varepsilon(\lambda)$ compared with their counterparts in group II, showed major differences in 
both positions and intensities: B1-3 (centered at around $\sim 323 \mathrm{~nm}$ ) had red-shift compared to B4 and B5 (centered at around $\sim 312 \mathrm{~nm}$ ). Furthermore, for the absorption peak ranges within 400-600 nm, dyes in group II, which were centered at $\sim 490, \sim 503, \sim 493, \sim 500$, and $\sim 503 \mathrm{~nm}$ for P1-5, respectively, showed slight blue-shift, but larger $\varepsilon(\lambda)$ compared with their counterparts in group I, which were centered at $\sim 495, \sim 510, \sim 500, \sim 508$, and $\sim 513 \mathrm{~nm}$ for B1-5, respectively. In addition, the absorption intensities of dyes in both group I and group II followed the identical sequence of B3 (P3) < B1 (P1) < B2 (P2) < B5 (P5) < B4 (P4). It is noteworthy that although B1 (P1) and B3 (P3) exhibited relatively small absorption intensities in the two main peaks, they showed better spectral response in the long wavelength region due to an absorption tail that was observed in the red region, which was centered at $\sim 610$ and $\sim 606 \mathrm{~nm}$ for B1 and B3, respectively ( 609 and $\sim 600 \mathrm{~nm}$ for P1 and P3, respectively). This indicated that introducing cyanoacrylic acid and nitric acid as anchoring groups can broaden absorption range and thus improve the light-harvesting properties of $\mathrm{Cu}(\mathrm{I})$-based dyes. In particular, relative to group II, all of the dyes in group I had an additional peak around $\sim 437 \mathrm{~nm}$, extending the spectral range. It was clear that dyes with bpy ligand had broader spectral coverage, while dyes with dmp ligand had stronger intensities in two major absorption peaks. Finally, it should be pointed out that the maximum absorption wavelengths of all the studied $\mathrm{Cu}(\mathrm{I})$-based complexes had different degrees of red-shift compared with that of the calibration compounds, $\left[\mathrm{Cu}\left(\mathrm{bpy}(\mathrm{Mes})_{2}\right)(\mathrm{phen})\right] \mathrm{BF} 4$ and $\left[\mathrm{Cu}\left(\mathrm{bpy}(\mathrm{Mes})_{2}\right)(\mathrm{dmp})\right] \mathrm{BF} 4$, which was mainly due to the extended aromatic system in the newly designed $\mathrm{Cu}(\mathrm{I})$-based dyes.

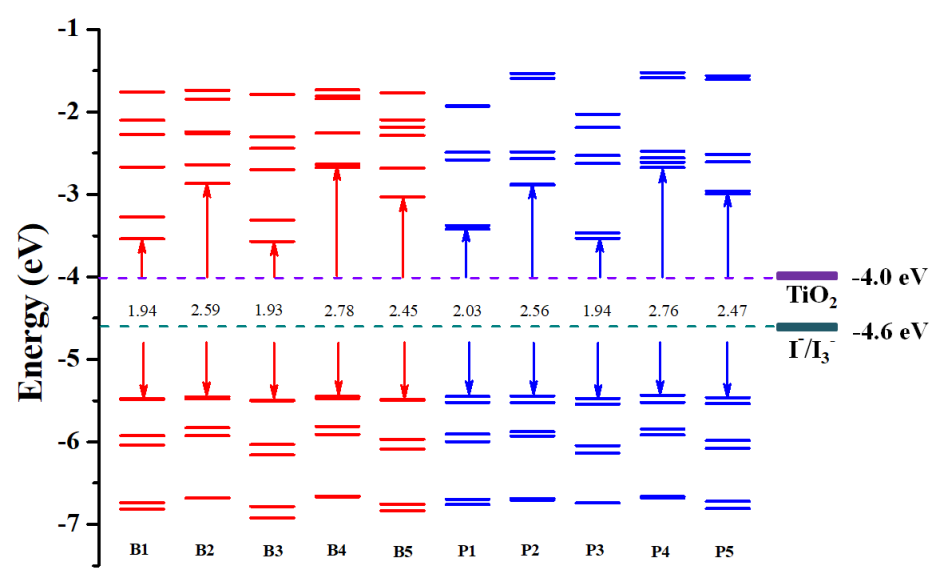

Figure 3. The molecular orbital energy levels from HOMO-5 to LUMO+5 and HOMO-LUMO energy gaps of all the studied $\mathrm{Cu}(\mathrm{I})$-based dyes.

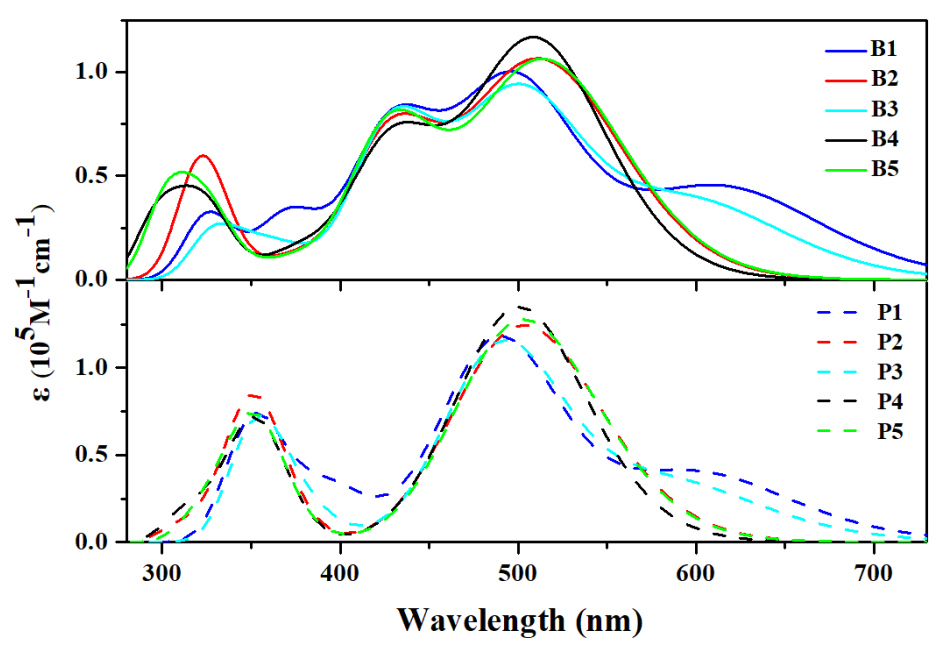

Figure 4. The calculated absorption spectra of all the studied $\mathrm{Cu}(\mathrm{I})$-based dyes. 
In order to gain more information about the light excitations in the studied $\mathrm{Cu}(\mathrm{I})$-based dyes, the vertical excitation energies, oscillator strengths, and relative orbital contributions of the optical transitions between 400 and $650 \mathrm{~nm}$ for the studied Cu(I)-based dyes are listed in Table S2. Next, we began to assess the IET routes upon photo-excitations based on the excitation information from Table S2 (Supplementary Materials) and the FMO distribution from Figure 2. Considering the similarity in absorption peak and intensity, only B1, B2, and B4 (P1, P2, and P4) with the excitation spectral range over $450 \mathrm{~nm}$ were selected to be assessed. For dye B1, the transition patterns in the first absorption band within the range of 579.6-625.7 nm contained several typical metal-to-ligand charge transfer (MLCT) transitions (HOMO-2 $\rightarrow$ LUMO/LUMO+1) and a ligand-to-ligand charge transfer $(\mathrm{LLCT})$ transition $(\mathrm{HOMO}-1 \rightarrow \mathrm{LUMO}+1)$, which was from the electron donor groups to the electron acceptor groups that could form superior charge-separated state to hinder electron recombination. Noticeably, the arriving orbitals of LUMO and LUMO+1 for these transitions were both delocalized over the whole electron acceptor groups, which was beneficial for electron injection according to the MO analysis. In addition, for the absorption band in the range of 491.8-502.0 nm in dye B1, the transitions mainly originated from $\mathrm{HOMO} / \mathrm{HOMO}-1 \rightarrow \mathrm{LUMO}+2$. Unfortunately, the transitions were invalid for charge separation and electron injection since the arriving orbital of LUMO+2 had no contribution from the anchoring group. Dye P1 showed a transition behavior similar to that of B1 with two absorption bands located at $\sim 490$ and $\sim 588 \mathrm{~nm}$. The transitions of the first absorption peak mainly composed of transitions HOMO-2 $\rightarrow$ LUMO (95\%) with oscillator strength 0.100 at $630.6 \mathrm{~nm}$ and $\mathrm{HOMO}-2 \rightarrow \mathrm{LUMO}+1(86 \%)$ with oscillator strength 0.447 at $597.3 \mathrm{~nm}$, which were beneficial for electron injection. However, the absorption band at $490 \mathrm{~nm}$, which was mainly composed of transitions originated from $\mathrm{HOMO} / \mathrm{HOMO}-1 \rightarrow \mathrm{LUMO}+2$ in the range of $487.6-496.7 \mathrm{~nm}$, were invalid for charge separation and electron injection because only LUMO/LUMO+1 had distribution on the electron acceptor subunit. Furthermore, transition behavior similar to that of B1/P1 was also found in both B3 and P3. In addition, there was one effective absorption excitation in each of the dyes B2 and P2, located at $538.2 \mathrm{~nm}$ with oscillator strength 0.739 and at $532.2 \mathrm{~nm}$ with oscillator strength 0.661 , respectively. The transitions were mainly composed of $\mathrm{HOMO}-2 \rightarrow \mathrm{LUMO}(55 \%) / \mathrm{HOMO} \rightarrow \mathrm{LUMO}+1$ (33\%) for $\mathrm{B} 2$ and $\mathrm{HOMO}-2 \rightarrow \mathrm{LUMO}(55 \%) / \mathrm{HOMO} \rightarrow \mathrm{LUMO}+2$ (28\%) for P2, which showed typical MLCT or LLCT and were beneficial for charge separation. As for dyes B4, B5, P4, and P5, since their arriving orbitals had little contributions from the electron acceptor group, their transitions were unfavorable for electron injection from dyes to the conduction band of $\mathrm{TiO}_{2}$. Based on the above observations, we concluded that the anchoring groups in $\mathrm{Cu}(\mathrm{I})$-based dyes had significant influence on electron transition and that cyanoacrylic acid and nitric acid can be used as suitable anchoring groups to generate efficient transition, thus improving IET and electron injection.

\subsection{Excited State Lifetime}

The excited state lifetime $(\tau)$ is one of the important factors to evaluate the electron transfer efficiency. A dye with a longer excited state lifetime is expected to be more susceptible to charge transfer [32]. The excited state lifetime of dyes can be evaluated by:

$$
\tau=1.499 / f E^{2}
$$

where $E$ is the excitation energy $\left(\mathrm{cm}^{-1}\right)$ and $f$ is the oscillator strength of the excited state. According to Equation (2), the excited state lifetime $(\tau)$ was calculated and is listed in Table 2. The calculated excited state lifetime $(\tau)$ of all the dyes in group I decreased in the order of B2 (5.89 ns) > B1 (5.55 ns) $>\mathrm{B} 4(5.18 \mathrm{~ns})>\mathrm{B} 3(4.89 \mathrm{~ns})>\mathrm{B} 5(4.39 \mathrm{~ns})$, and $\tau$ of all the dyes in group II decreased in the order of P4 $(6.48 \mathrm{~ns})>\mathrm{P} 2(6.42 \mathrm{~ns})>\mathrm{P} 1(3.39 \mathrm{~ns})>\mathrm{P} 3(3.38 \mathrm{~ns})>\mathrm{B} 5(2.53 \mathrm{~ns})$. The calculated results indicated that dyes B1/P1 (with cyanoacrylic acid anchoring group), B2/P2 (with carboxylic acid anchoring group), and B4/P4 (with phosphoric acid anchoring group) can facilitate change transfer by prolonging the excited state lifetime and may further enhance the short-circuit current density in DSSCs. 
Table 2. The optical properties and intramolecular electron transfer (IET) parameters of the studied dyes.

\begin{tabular}{|c|c|c|c|c|c|c|}
\hline Dyes & $\tau / \mathrm{ns}$ & $\Delta \mathrm{H}-\mathrm{L}^{2} / \mathrm{eV}$ & $q^{E T} / e$ & $\mathrm{~d}^{\mathrm{ET}} / \AA$ & H/Å & $t / \AA$ \\
\hline B1 & 5.55 & 1.94 & 0.687 & 3.579 & 5.281 & -1.702 \\
\hline B2 & 5.89 & 2.59 & 0.604 & 1.537 & 5.234 & -3.697 \\
\hline B3 & 4.89 & 1.93 & 0.639 & 3.746 & 5.122 & -1.376 \\
\hline B4 & 5.18 & 2.78 & 0.628 & 1.134 & 5.607 & -4.473 \\
\hline B5 & 4.39 & 2.45 & 0.614 & 2.189 & 5.225 & -3.036 \\
\hline P1 & 3.39 & 2.03 & 1.075 & 3.618 & 4.948 & -1.330 \\
\hline P2 & 6.42 & 2.56 & 0.615 & 2.107 & 5.280 & -3.173 \\
\hline P3 & 3.38 & 1.94 & 1.036 & 3.397 & 4.568 & -1.171 \\
\hline P4 & 6.48 & 2.76 & 0.622 & 1.442 & 5.677 & -4.235 \\
\hline P5 & 2.53 & 2.47 & 0.690 & 3.977 & 6.002 & -2.025 \\
\hline
\end{tabular}

\subsection{Intramolecular Electron Transfer}

In this section, to further investigate the IET characteristics, the electronic density difference (EDD) plots between the ground and excited states of the studied $\mathrm{Cu}(\mathrm{I})$-based dyes were also calculated and were shown in Figure 5. Apparently, except for B4 and P4, the region of electron density depletion (red color) for all the dyes mostly localized at the donor subunits and $\mathrm{Cu}(\mathrm{I})$ center ligand, while the region of electron density increment (green color) was largely aligned with the anchoring groups, indicating an effective charge-separated state for DSSC application. While for B4 and P4, the most majority of increased electron density was located at almost the whole complex skeleton, not on the anchor group, which would result in a serious intramolecular electron recombination and low-efficiency electron injection to the semiconductor. Among all the studied dyes, B1/P1 (with cyanoacrylic acid anchoring group) and B3/P3 (with nitric acid anchoring group) presented a superior charge-separated state, which indicated that these dyes would have great performance of electron injection and could inhibit electron recombination effectively.

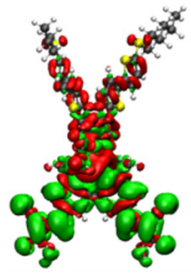

B1

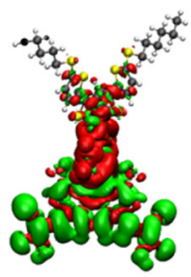

P1

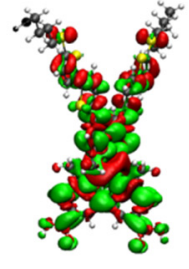

B2

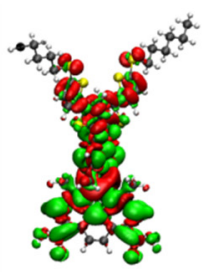

P2

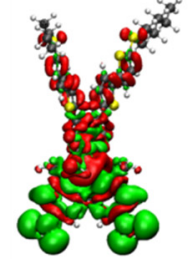

B3

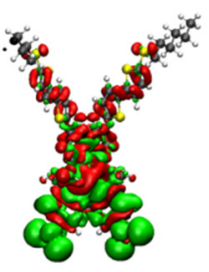

P3

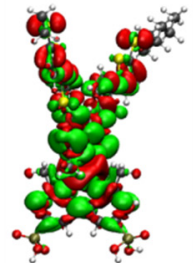

B4

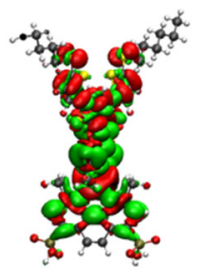

P4

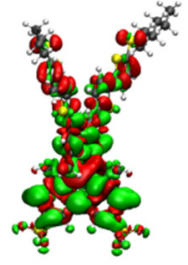

B5

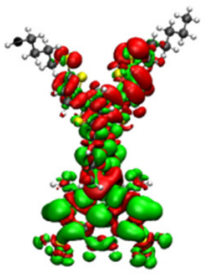

P5

Figure 5. The electron density differences $(\Delta \rho)$ for the studied dyes. The red surface identifies the region in which the electron density decreases. The green surface identifies the region in which the electron density increases.

Furthermore, in order to quantitatively evaluate the charge transfer characteristics of the studied $\mathrm{Cu}(\mathrm{I})$-based dyes, charge transfer parameters, including transferred charge $\left(\mathrm{q}^{\mathrm{ET}}\right)$, electron transfer distance $\left(\mathrm{d}^{\mathrm{ET}}\right), H$, and $t$ of the lowest excitation states were calculated with Multiwfn [25], and the results were listed in Table 2. For more calculation details about the abovementioned parameters, please refer to these publications [33-36]. 
As seen in Table 2, the values of transferred charge $\mathrm{q}^{\mathrm{ET}}$ fluctuated in the range of 0.604-0.687 e with the sequence of $\mathrm{B} 2<\mathrm{B} 5<\mathrm{B} 4<\mathrm{B} 3<\mathrm{B} 1$ in group I, while the values fluctuated in the range of 0.614-1.075 e with the sequence of P2 $<$ P4 $<$ P5 $<$ P3 $<$ P1 in group II. It was clear that dyes with cyanoacrylic acid as the anchoring group could transfer more electrons upon photo-excitation. As for the values of $\mathrm{d}^{\mathrm{ET}}$, they fluctuated in the range of 1.134-3.746 $\AA$, with the sequence of $\mathrm{B} 4<\mathrm{B} 2<\mathrm{B} 5$ $<\mathrm{B} 1<\mathrm{B} 3$ in group I, while they fluctuated in the range of 1.442-3.977 $\AA$, with the sequence of P4 $<\mathrm{P} 2<\mathrm{P} 3<\mathrm{P} 1<\mathrm{P} 5$ in group II. The value of $t$ was in the order of $-4.473 \AA$ (B4) $<-3.697 \AA$ (B2) $<-3.306 \AA(\mathrm{B} 5)<-1.702 \AA$ (B1) $<-1.376 \AA$ (B3) in group I, and the same sequence was found in group II. The more positive $t$ value reflected the downward trend in the orbital overlap, demonstrating a lower recombination possibility. Considering the index $\mathrm{q}^{\mathrm{ET}}, \mathrm{d}^{\mathrm{ET}}$ combined with $t, \mathrm{~B} 1 / \mathrm{P} 1$ (with cyanoacrylic acid anchoring group) and B3/P3 (with nitric acid anchoring group) exhibited outstanding IET characteristics. Among them, P1 performed the best due to most electrons that could be transferred with longer distance and lower orbital overlap.

\subsection{Electron Structures of Dye/(TiO $\left.{ }_{2}\right)_{38}$ Systems}

In order to investigate the interaction between dye molecules and $\mathrm{TiO}_{2}$ interface, an analysis of the electron injection capability of dyes and the adsorption of dyes on the anatase $\mathrm{TiO}_{2}(101)$ surface was performed with DFT calculations using the Dmol3 program [37,38]. Dyes B1-B5 (group I) and P1-P5 (group II) adsorbed onto the $\mathrm{TiO}_{2}$ surface with a bidentate bridging manner, which has been proved to be the most stable chemisorption model for the simulation of dye/ $\mathrm{TiO}_{2}$ systems $[39,40]$. The dye/( $\left.\left.\mathrm{TiO}\right)_{2}\right)_{38}$ systems were optimized using the density functional theory (DFT) by employing the generalized gradient approximation (GGA) [41] with the Perdew-Burke-Ernzerhof (PBE) functional [42,43] and DNP (double numerical basis set with polarization) basis set.

The optimized geometries and FMOs of all the $\mathrm{Cu}(\mathrm{I})$-based dye/( $\left.\mathrm{TiO}_{2}\right)_{38}$ systems were depicted in Table 3. The HOMOs were mainly distributed on the entire dyes, while the LUMOs were localized on the $\left(\mathrm{TiO}_{2}\right)_{38}$ clusters except for $\mathrm{B} 3$, indicating excellent electron injection capacity from dyes to the $\mathrm{TiO}_{2}$ cluster. To further investigate the light-harvesting abilities, the values of HOMOs, LUMOs, and $\Delta H-L$ of dye- $\left(\mathrm{TiO}_{2}\right)_{38}$ combined systems were also calculated and were listed in Table 3 . The $\Delta \mathrm{H}$-L of group I decreased in the order of B3 $>$ B2 $>$ B5 $>$ B1 $>$ B4, and the order of group II was P5 $>$ P3 $>$ P4 $>$ P1 $>$ P2 . Among them, the low $\Delta \mathrm{H}-\mathrm{L}$ of $\mathrm{B} 4$ and $\mathrm{P} 2$ indicated their excellent light-harvesting abilities.

Table 3. The optimized structures and frontier molecular orbitals (with an isodensity of $0.01 \mathrm{au}$ ) for dye/( $\left(\mathrm{TiO}_{2}\right)_{38}$ systems.

\begin{tabular}{|c|c|c|c|c|c|}
\hline Dye $/\left(\mathrm{TiO}_{2}\right)_{38}$ & $\mathrm{~B} 1 /\left(\mathrm{TiO}_{2}\right)_{38}$ & $\mathrm{~B} 2 /\left(\mathrm{TiO}_{2}\right)_{38}$ & $\mathrm{~B} 3 /\left(\mathrm{TiO}_{2}\right)_{38}$ & $\mathrm{~B} 4 /\left(\mathrm{TiO}_{2}\right)_{38}$ & $\mathrm{~B} 5 /\left(\mathrm{TiO}_{2}\right)_{38}$ \\
\hline Structure & & & & & \\
\hline HOMO & & 䃇 & & & 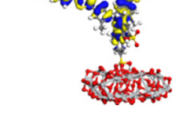 \\
\hline LUMO & 2 & & & & \\
\hline
\end{tabular}


Table 3. Cont.

\begin{tabular}{|c|c|c|c|c|c|}
\hline $\mathrm{Dye} /\left(\mathrm{TiO}_{2}\right)_{38}$ & $\mathrm{P} 1 /\left(\mathrm{TiO}_{2}\right)_{38}$ & $\mathrm{P} 2 /\left(\mathrm{TiO}_{2}\right)_{38}$ & $\mathrm{P} 3 /\left(\mathrm{TiO}_{2}\right)_{38}$ & $\mathrm{P} 4 /\left(\mathrm{TiO}_{2}\right)_{38}$ & $\mathrm{P} 5 /\left(\mathrm{TiO}_{2}\right)_{38}$ \\
\hline Structure & & & & & 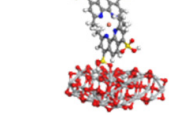 \\
\hline HOMO & 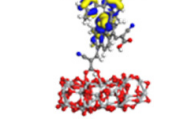 & & & & 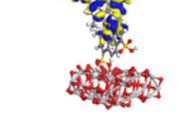 \\
\hline LUMO & (2) & & (2) & & g \\
\hline
\end{tabular}

It is well-known that the PCE of DSSCs can be determined by the short-circuit current density $\left(\mathrm{J}_{\mathrm{sc}}\right)$, open-circuit photo-voltage $\left(\mathrm{V}_{\mathrm{oc}}\right)$, and fill factor $(\mathrm{FF})$. Next, the key parameters affecting $\mathrm{J}_{\mathrm{sc}}$ and $\mathrm{V}_{\mathrm{oc}}$ from the view of molecular design and evaluation will be discussed. The following expressions (3)-(6) are from references [44-47]. The $\mathrm{V}_{\text {oc }}$ can be described by:

$$
\mathrm{V}_{\mathrm{OC}}=\frac{\mathrm{E}_{\mathrm{CB}}+\Delta \mathrm{E}_{\mathrm{CB}}}{q}+\frac{\mathrm{k}_{\mathrm{B}} \mathrm{T}}{q} \ln \left(\frac{\mathrm{n}_{\mathrm{c}}}{\mathrm{N}_{\mathrm{CB}}}\right)-\frac{\mathrm{E}_{\text {redox }}}{q}
$$

where $q$ is the unit charge, $\mathrm{E}_{\mathrm{CB}}$ is the conduction band edge of the semiconductor substrate, $\Delta \mathrm{E}_{\mathrm{CB}}$ is the level shift of conduction band edge of $\mathrm{TiO}_{2}$ due to dye adsorption, $\mathrm{k}_{\mathrm{B}}$ is the Boltzmann constant, $T$ is the absolute temperature, $n_{c}$ is the number of electrons in the conduction band, $N_{C B}$ is the density of accessible states in the conduction band, and $E_{\text {redox }}$ is the electrolyte Fermi level. $\Delta \mathrm{E}_{\mathrm{CB}}$ can be expressed as:

$$
\Delta \mathrm{E}_{\mathrm{CB}}=-\frac{q \mu_{\text {normal }} \gamma}{\varepsilon_{0} \varepsilon}
$$

where $\mu_{\text {normal }}$ denotes the dipole moment of the individual sensitizer perpendicular to the surface of the $\mathrm{TiO}_{2}$ semiconductor, $\gamma$ is the surface concentration of dyes, and $\varepsilon_{0}$ and $\varepsilon$ represent the vacuum permittivity and dielectric permittivity of the dipole layer, respectively. It is obvious that a dye with larger $\mu_{\text {normal }}$ will lead to more $\Delta \mathrm{E}_{\mathrm{CB}}$ shift, resulting in larger $\mathrm{V}_{\mathrm{oc}}$. As illustrated in Table 4, the calculated $\mu_{\text {normal }}$ values of B1-B5 (group I) were in the following order: B1 (14.99 D) > B4 (14.93 D) $>$ B2 $(12.78 \mathrm{D})>\mathrm{B} 5(7.44 \mathrm{D})>\mathrm{B} 3(6.95 \mathrm{D})$; and $\mu_{\text {normal }}$ values of P1-P5 (group II) were in the following order: P1 $(15.95 \mathrm{D})>\mathrm{P} 4(15.82 \mathrm{D})>\mathrm{P} 2(13.06 \mathrm{D})>\mathrm{P} 3(8.10 \mathrm{D})>\mathrm{P} 5(8.09 \mathrm{D})$. The calculated results indicated that dyes B1/P1 (with cyanoacrylic acid anchoring group), B2/P2 (with carboxylic acid anchoring group), and B4/P4 (with phosphoric acid anchoring group) could display a lager $\mu_{\text {normal }}$, which would lead to more $\triangle \mathrm{E}_{\mathrm{CB}}$ shift, resulting in larger $\mathrm{V}_{\mathrm{oc}}$ in DSSCs.

In DSSCs field, $\Delta G_{\text {inject }}$ is always used to evaluate the ability of electron injection upon photo-excitation from dyes into the conduction band of the semiconductor. As illustrated in Figure 6, $\Delta \mathrm{G}_{\text {inject }}$ can be defined as the difference between the excited-state oxidation potential of dye $\left(\mathrm{E}^{*}\right.$ dye $)$ and the conduction band energy level of semiconductor $\left(\mathrm{E}_{\mathrm{CB}}\right)$ :

$$
\Delta G_{\text {inject }}=E_{\text {dye }}^{*}-E_{C B}=\left(E_{\text {dye }}-E_{\lambda_{\max }}\right)-E_{C B}
$$

where $E_{\text {dye }}$ is the ground-state oxidation potential of dye, $E_{\lambda \max }$ is the lowest vertical transition energy corresponding to $\lambda_{\max }$, and $\mathrm{E}_{\mathrm{CB}}$ is the reduction potential of the conduction band edge of $\mathrm{TiO}_{2}$, which was widely used as $-4.0 \mathrm{eV}$ in a previous report [48]. On the other hand, the dye regeneration 
efficiency in excited state is also an important factor to evaluate the performance of DSSCs, which is always estimated through the regeneration driving force $\Delta \mathrm{G}_{\mathrm{reg}} . \Delta \mathrm{G}_{\mathrm{reg}}$ can be calculated from the difference between the ground-state oxidation potential and redox potential of the iodide/tri-iodide redox couple. As illustrated in Figure $6, \Delta \mathrm{G}_{\text {reg }}$ can be expressed as:

$$
\Delta \mathrm{G}_{\mathrm{reg}}=\mathrm{E}_{\mathrm{I}^{-} / \mathrm{I}_{3}^{-}}-\mathrm{E}_{\text {dye }}
$$

Table 4. Calculated energy level parameters (in eV), vertical dipole moment of the isolated dyes absorbed on $\left(\mathrm{TiO}_{2}\right)_{38}$ clusters (in Debye), and electron injection time (in fs) for the studied dye/( $\left.\mathrm{TiO}_{2}\right)_{38}$ systems.

\begin{tabular}{cccccc}
\hline System & HOMO & LUMO & $\boldsymbol{\Delta} \mathbf{H}-\mathbf{L}$ & $\boldsymbol{\mu}_{\text {normal }}$ & $\boldsymbol{\tau}_{\text {inj }}$ \\
\hline B1 & -4.87 & -4.30 & 0.57 & 14.99 & 13.92 \\
B2 & -5.04 & -4.34 & 0.70 & 12.78 & 16.59 \\
B3 & -5.09 & -4.25 & 0.84 & 6.95 & 16.71 \\
B4 & -4.57 & -4.24 & 0.33 & 14.93 & 15.78 \\
B5 & -4.82 & -4.20 & 0.62 & 7.44 & 15.88 \\
P1 & -4.85 & -4.40 & 0.45 & 15.95 & 12.81 \\
P2 & -4.70 & -4.28 & 0.42 & 13.06 & 15.17 \\
P3 & -5.10 & -4.26 & 0.84 & 8.10 & 15.27 \\
P4 & -5.04 & -4.35 & 0.69 & 15.82 & 14.99 \\
P5 & -5.10 & -4.25 & 0.85 & 8.09 & 15.10 \\
\hline
\end{tabular}

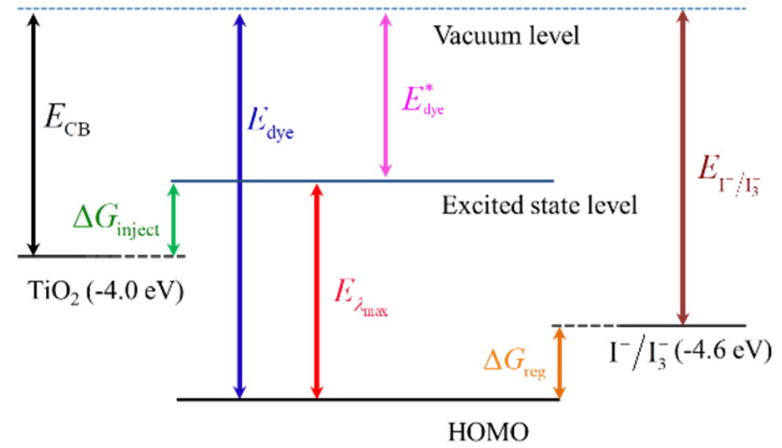

Figure 6. Energy level alignment of a dye-sensitized solar cell [47].

The calculated $E_{\text {dye }}, E_{\text {dye }}^{*}, \Delta G_{\text {inject }}$, and $\Delta G_{\text {reg }}$ values for the investigated dyes are listed in Table 5. As shown in Table 5, for all the studied dyes, the absolute values of $\Delta G_{\text {inject }}$ and $\Delta G_{\text {reg }}$ were larger than $0.3 \mathrm{eV}$. It was reported that the efficient electron injection and dye regeneration process in DSSCs should require the absolute values of $\Delta \mathrm{G}_{\text {inject }}$ and $\Delta \mathrm{G}_{\mathrm{reg}}$ to be at least $0.2 \mathrm{eV}[6,49]$. Therefore, we can conclude that the energy alignment of all the investigated dye/( $\left.\mathrm{TiO}_{2}\right)_{38}$ systems could guarantee effective interface charge injection and fast dye regeneration.

Table 5. Parameters of interfacial electron injection and dye regeneration.

\begin{tabular}{ccccccc}
\hline Dyes & $\mathbf{E}^{\text {dye }}$ & $\lambda_{\max }$ & $\mathbf{E}_{\boldsymbol{\lambda} \max }$ & $\mathbf{E}^{\text {dye }}$ & $\Delta \mathbf{G}_{\text {inj }}$ & $\Delta \mathbf{G}_{\text {reg }}$ \\
\hline B1 & -5.42 & 1.98 & -1.98 & -3.44 & 0.56 & 0.82 \\
B2 & -5.41 & 2.30 & -2.30 & -3.11 & 0.89 & 0.81 \\
B3 & -5.47 & 2.05 & -2.05 & -3.42 & 0.58 & 0.87 \\
B4 & -5.39 & 2.36 & -2.36 & -3.03 & 0.97 & 0.79 \\
B5 & -5.44 & 2.29 & -2.29 & -3.15 & 0.85 & 0.84 \\
P1 & -5.29 & 1.97 & -1.97 & -3.32 & 0.68 & 0.69 \\
P2 & -5.38 & 2.33 & -2.33 & -3.05 & 0.95 & 0.78 \\
P3 & -5.38 & 1.96 & -1.96 & -3.42 & 0.58 & 0.78 \\
P4 & -5.33 & 2.36 & -2.36 & -2.97 & 1.03 & 0.73 \\
P5 & -5.46 & 2.33 & -2.33 & -3.13 & 0.87 & 0.86 \\
\hline
\end{tabular}


The electron injection time $\left(\tau_{\text {inj }}\right)$ is also a vital parameter to determine the electron transfer processes in DSSCs. The $\tau_{\text {inj }}$ can be calculated as follows [50,51]:

$$
\begin{gathered}
\tau_{\text {inj }}=658 / \Delta(\mathrm{meV}) \\
\Delta=\sum P_{\mathrm{i}} \mid \varepsilon_{\mathrm{i}}-\mathrm{E}_{\mathrm{LUMO}}(\text { ads }) \mid
\end{gathered}
$$

where $\Delta$ is energetic broadening, $P_{\mathrm{i}}$ is the adsorbate portion of every molecular orbital, $\varepsilon_{\mathrm{i}}$ is orbital energy, and $\mathrm{E}_{\mathrm{LUMO}}$ (ads) is energy of the adsorbate's LUMO. Based on the optimized dye/( $\left.\mathrm{TiO}_{2}\right)_{38}$ geometries, the calculated $\tau_{\text {inj }}$ of electrons from the excited state of the $\mathrm{Cu}(\mathrm{I})$-based dyes to the conduction band of $\mathrm{TiO}_{2}$ was in the range of 12.81-16.59 fs, with the order of $\mathrm{B} 1(13.92)<\mathrm{B} 4(15.78)$ $<$ B5 $(15.88)<$ B2 $(16.59)<$ B3 (16.71) in group I, and P1 $(12.81)<$ P4 (14.99) < P5 (15.10) < P2 (15.17) $<$ P3 (15.27) in group II. It was clear that dyes in group II (based on dmp ligand) exhibited faster electron injection than dyes in group I (based on bpy ligand). Among all the studied Cu(I)-based dyes, B1/ P1 (with cyanoacrylic acid anchoring group) exhibited the best electron injection behavior with relative shorter $\tau_{\text {inj, }}$ which would have a positive effect on the short-circuit current density $\left(\mathrm{J}_{\mathrm{sc}}\right)$ in DSSCs.

\section{Conclusions}

In this study, two groups of heteroleptic $\mathrm{Cu}(\mathrm{I})$-based dyes were designed and theoretically investigated by density functional theory (DFT) and time-dependent DFT (TD-DFT) methods. Different anchors were integrated into the dye skeleton to shed light on how the type of anchor influenced the electronic structure, absorption spectrum, electron excitation, and intramolecular and interfacial electron transfer of dyes. The main points are summarized as follows:

(1) All the studied $\mathrm{Cu}(\mathrm{I})$-based dyes were inclined to form distorted trigonal pyramidal geometries. The anchoring group had little effect on the geometry structure of the dye.

(2) All the studied $\mathrm{Cu}(\mathrm{I})$-based dyes exhibited good light-harvesting abilities with absorption band cover in the $260-750 \mathrm{~nm}$ range. The results indicated that the anchoring groups can efficiently tune the spectral range as well as absorption intensity and that introducing cyanoacrylic acid and nitric acid as anchoring groups can effectively decrease the HOMO-LUMO energy gap, broaden the absorption range, and thus promote the light-harvesting properties of the $\mathrm{Cu}(\mathrm{I})$-based dyes.

(3) Dyes with cyanoacrylic acid or nitric acid as the anchoring group (B1, B3, P1, and P3) can transfer more electrons with longer distance and weaker orbital overlap and can form favorable electron-separated state. Compared with other studied dyes, dyes with carboxylic acid as the anchoring group (B2 and P2) transferred electrons faster.

(4) Among all the studied $\mathrm{Cu}(\mathrm{I})$-based dyes, B1(P1) with cyanoacrylic acid group exhibited the best interface electronic structure parameters with a relatively short electron injection time $\tau_{\text {inj }}$ and large dipole moment $\mu_{\text {normal, }}$ which would have a positive effect on the open-circuit photo-voltage $\left(\mathrm{V}_{\mathrm{oc}}\right)$ and short-circuit current density $\left(\mathrm{J}_{\mathrm{sc}}\right)$, resulting in high PCE of DSSCs.

Supplementary Materials: The following are available online, Figure S1: Simulated absorption spectra of phen- and dmp-based dyes at the B3LYP/6-31G(d), B3LYP/DZVP, and B3LYP/LanL2DZ levels, Figure S2: The frontier molecular orbitals of dyes B2, B3, B5, P2, P3, and P5, Table S1: Calculated UV/VIS results compared with experimental and theoretical studies (nm), Table S2: The lowest excitation state parameters of all the investigated dyes.

Author Contributions: Conceptualization, Z.X. and X.L.; software, Y.L. and S.W.; validation, Y.L. and S.W.; formal analysis, Z.X. and X.L.; investigation, Z.X.; writing-original draft preparation, Z.X.; writing-review and editing, X.L. and S.W.; project administration, S.W.; funding acquisition, S.W. All authors have read and agreed to the published version of the manuscript.

Funding: This research was funded by Shandong Natural Science Foundation, China (ZR2017MA024), the Fundamental Research Funds for the Central Universities (18CX02038A and 18CX05011A), and the Training Programs of Innovation and Entrepreneurship for Undergraduates (UPC, 20181447).

Acknowledgments: The authors thank all the teachers and students in our research group for their helpful cooperation and discussions. The authors thank PetroChina Tarim Oilfield for its help and cooperation. 
Conflicts of Interest: The authors declare no conflict of interest.

\section{References}

1. O'Regan, B.; Grätzel, M. A low-cost, high-efficiency solar cell based on dye-sensitized colloidal TiO $\mathrm{Tilms}_{2}$ Nature 1991, 353, 737-740. [CrossRef]

2. Nazeeruddin, M.K.; Kay, A.; Rodicio, I.; Humphry-Baker, R.; Muller, E.; Liska, P.; Vlachopoulos, N.; Grätzel, M. Conversion of Light to Electricity by cis- $\mathrm{X}_{2} \operatorname{Bis}\left(2,2^{\prime}\right.$-bipyridyl-4,4'-dicarboxylate) ruthenium (II) Charge-Transfer Sensitizers (X = C1-, Br-, I-, CN-, and SCN-) on Nanocrystalline $\mathrm{TiO}_{2}$ Electrodes. J. Am. Chem. Soc. 1993, 115, 6382-6390. [CrossRef]

3. Nazeeruddin, M.K.; De Angelis, F.; Fantacci, S.; Selloni, A.; Viscardi, G.; Liska, P.; Ito, S.; Takeru, B.; Grätzel, M. Combined experimental and DFT-TDDFT computational study of photoelectrochemical cell ruthenium sensitizers. J. Am. Chem. Soc. 2005, 127, 16835-16847. [CrossRef] [PubMed]

4. Adeloye, A.O.; Ajibade, P.A. Towards the Development of Functionalized Polypyridine Ligands for Ru(II) Complexes as Photosensitizers in Dye-Sensitized Solar Cells (DSSCs). Molecules 2014, 19, 12421-12460. [CrossRef] [PubMed]

5. Chou, C.C.; Wu, K.L.; Chi, Y.; Hu, W.P.; Yu, S.J.; Lee, G.H.; Lin, C.L.; Chou, P.T. Ruthenium (II) Sensitizers with Heteroleptic Tridentate Chelates for Dye-Sensitized Solar Cells. Angew. Chem. 2011, 123, 2102-2106. [CrossRef]

6. Grätzel, M. Recent Advances in Sensitized Mesoscopic Solar Cells. Acc. Chem. Res. 2009, 42, $1788-1798$. [CrossRef]

7. Funaki, T.; Funakoshi, H.; Kitao, O.; Onozawa-Komatsuzaki, N.; Kasuga, K.; Sayama, K.; Sugihara, H. Cyclometalated Ruthenium (II) Complexes as Near-IR Sensitizers for High Efficiency Dye-Sensitized Solar Cells. Angew. Chem. 2012, 124, 7646-7649. [CrossRef]

8. Anthonysamy, A.; Lee, Y.; Karunagaran, B.; Ganapathy, V.; Rhee, S.-W.; Karthikeyan, S.; Kim, K.S.; Ko, M.J.; Park, N.-G.; Ju, M.-J.; et al. Molecular design and synthesis of ruthenium(II) sensitizers for highly efficient dye-sensitized solar cells. J. Mater. Chem. 2011, 21, 12389. [CrossRef]

9. Aghazada, S.; Nazeeruddin, M.K. Ruthenium Complexes as Sensitizers in Dye-Sensitized Solar Cells. Inorganics 2018, 6, 52. [CrossRef]

10. Alonso-Vante, N.; Nierengarten, J.-F.; Sauvage, J.-P. Spectral sensitization of large-band-gap semiconductors (Thin films and Ceramics) by a carboxylated bis(1,10-phenanthroline)copper (I) complex. J. Chem. Soc. Dalton Trans. 1994, 11, 1649-1654. [CrossRef]

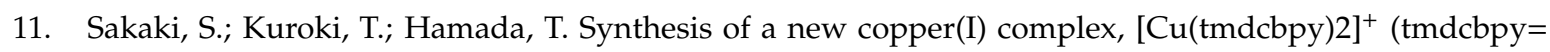
4,4',6,6'-tetramethyl-2,2'-bipyridine-5,5'-dicarboxylic acid), and its application to solar cells. J. Chem. Soc. Dalton Trans. 2002, 6, 840-842. [CrossRef]

12. Hattori, S.; Wada, Y.; Yanagida, S.; Fukuzumi, S. Blue Copper Model Complexes with Distorted Tetragonal Geometry Acting as Effective Electron-Transfer Mediators in Dye-Sensitized Solar Cells. J. Am. Chem. Soc. 2005, 127, 9648-9654. [CrossRef] [PubMed]

13. Bessho, T.; Constable, E.C.; Graetzel, M.; Redondo, A.H.; Housecroft, C.E.; Kylberg, W.; Nazeeruddin, M.K.; Neuburger, M.; Schaffner, S. An element of surprise-Efficient copper-functionalized dye-sensitized solar cells. Chem. Comm. 2008, 3717-3719. [CrossRef] [PubMed]

14. Bozic-Weber, B.; Brauchli, S.Y.; Constable, E.C.; Fürer, S.O.; Housecroft, C.E.; Malzner, F.J.; Wright, I.A.; Zampese, J.A. Improving the photoresponse of copper(I) dyes in dye-sensitized solar cells by tuning ancillary and anchoring ligand modules. Dalton Trans. 2013, 42, 12293-12308. [CrossRef] [PubMed]

15. Sandroni, M.; Favereau, L.; Planchat, A.; Akdas-Kilig, H.; Szuwarski, N.; Pellegrin, Y.; Blart, E.; Bozec, H.L.; Boujtita, M.; Odobel, F. Heteroleptic copper (i)-polypyridine complexes as efficient sensitizers for dye sensitized solar cells. J. Mater. Chem. A 2014, 2, 9944-9947. [CrossRef]

16. Lu, X.; Wei, S.; Lawrence Wu, C.-M.; Li, S.; Guo, W. Can Polypyridyl Cu(I)-based Complexes Provide Promising Sensitizers for Dye-Sensitized Solar Cells? A Theoretical Insight into Cu(I) versus Ru(II) Sensitizers. J. Phys. Chem. C 2011, 115, 3753-3761. [CrossRef]

17. Wei, S.; Shi, X.; Lu, X.; Shao, Y.; Jin, D.; Deng, Z.; Zhao, Z.; Li, K.; Guo, W. Cu (I)-Based Sensitizers Featuring 6, 6'-Dimethyl-4, 4'-Dicarboxylate-2, 2'-Bipyridine with Functionalized 2, 9-Dimethyl-1, 10-Phenanthroline Ligands: A Structural, Electronic and Spectral Investigation. Sci. Adv. Mater. 2015, 7, 1361-1367. [CrossRef] 
18. Wei, S.; Shao, Y.; Shi, X.; Lu, X.; Li, K.; Zhao, Z.; Guo, C.; Zhu, H.; Guo, W. Heteroleptic Cu(I) complexes integrating functionalized chromophores for dye-sensitized solar cells: An in-depth analysis of electronic structure, spectrum, excitation, and intramolecular electron transfer. Org. Electron. 2016, 29, 142-150. [CrossRef]

19. Wei, S.; Li, K.; Lu, X.; Zhao, Z.; Shao, Y.; Dang, Y.; Li, S.; Guo, W. Theoretical insight into electronic structure and optoelectronic properties of heteroleptic $\mathrm{Cu}$ (I)-based complexes for dye-sensitized solar cells. Mater. Chem. Phys. 2016, 173, 139-145. [CrossRef]

20. Frisch, M.J.; Trucks, G.W.; Schlegel, H.B.; Scuseria, G.E.; Robb, M.A.; Cheeseman, J.R.; Scalmani, G.; Barone, V.; Mennucci, B.; Petersson, G.A.; et al. Gaussian 09, Revision A.1; Gaussian Inc.: Wallingford, CT, USA, 2009.

21. Andersson, M.P.; Uvdal, P. New scale factors for harmonic vibrational frequencies using the B3LYP density functional method with the triple- $\zeta$ basis set 6-311+ G (d, p). J. Phys. Chem. A 2005, 109, 2937-2941. [CrossRef]

22. Curtiss, L.A.; Raghavachari, K.; Redfern, P.C.; Pople, J.A. Investigation of the use of B3LYP zero-point energies and geometries in the calculation of enthalpies of formation. Chem. Phys. Lett. 1997, 270, 419-426. [CrossRef]

23. Petersson, G.A.; Tensfeldt, T.G.; Montgomery, J.A. A complete basis set model chemistry. III. The complete basis set-quadratic configuration interaction family of methods. J. Chem. Phys. 1991, 94, 6091-6101. [CrossRef]

24. Chiodo, S.; Russo, N.; Sicilia, E. Newly developed basis sets for density functional calculations. J. Comput. Chem. 2005, 26, 175-184. [CrossRef] [PubMed]

25. Lu, T.; Chen, F. Multiwfn: A multifunctional wavefunction analyzer. J. Comput. Chem. 2012, 33, 580-592. [CrossRef] [PubMed]

26. Tomasi, J.; Mennucci, B.; Cammi, R. Quantum mechanical continuum solvation models. Chem. Rev. 2005, 105, 2999-3094. [CrossRef] [PubMed]

27. Barone, V.; Cossi, M.; Tomasi, J. A new definition of cavities for the computation of solvation free energies by the polarizable continuum model. J. Chem. Phys. 1997, 107, 3210-3221. [CrossRef]

28. Barone, V.; Cossi, M. Quantum Calculation of Molecular Energies and Energy Gradients in Solution by a Conductor Solvent Model. J. Phys. Chem. A 1998, 102, 1995-2001. [CrossRef]

29. Fraser, M.G.; Salm, H.V.D.; Cameron, S.A.; Blackman, A.G.; Gordon, K.C. Heteroleptic Cu(I) Bis-diimine Complexes of 6,6'-Dimesityl-2,2'-bipyridine: A Structural, Theoretical and Spectroscopic Study. Inorg. Chem. 2013, 52, 2980-2992. [CrossRef]

30. Chen, C.-Y.; Wang, M.; Li, J.-Y.; Pootrakulchote, N.; Alibabaei, L.; Ngoc-le, C.; Decoppet, J.-D.; Tsai, J.-H.; Grätzel, G.; Wu, C.-G.; et al. Highly Efficient Light-Harvesting Ruthenium Sensitizer for Thin-Film Dye-Sensitized Solar Cells. ACS Nano 2009, 3, 3103-3109. [CrossRef]

31. Yang, L.; Powell, D.R.; Houser, R.P. Structural variation in copper (i) complexes with pyridylmethylamide ligands: Structural analysis with a new four-coordinate geometry index, $\tau 4$. Dalton Trans. 2007, 955-964. [CrossRef]

32. Chaitanya, K.; Ju, X.-H.; Heron, B.M. Theoretical study on the light harvesting efficiency of zinc porphyrin sensitizers for DSSCs. RSC Adv. 2014, 4, 26621. [CrossRef]

33. He, L.-J.; Chen, J.; Bai, F.-Q.; Jia, R.; Wang, J.; Zhang, H.-X. Fine-tuning $\pi$-spacer for high efficiency performance DSSC: A theoretical exploration with D- $\pi$-A based organic dye. Dyes Pigm. 2017, 141, 251-261. [CrossRef]

34. Bahers, T.L.; Adamo, C.; Ciofini, I. A qualitative index of spatial extent in charge transfer excitations. J. Chem. Theory Comput. 2011, 7, 2498-2506. [CrossRef] [PubMed]

35. Jacquemin, D.; Bahers, T.L.; Adamo, C.; Ciofini, I. What is the best atomic charge model to describe through-space charge-transfer excitations? Phys. Chem. Chem. Phys. 2012, 14, 5383-5388. [CrossRef]

36. Ciofini, I.; Bahers, T.L.; Adamo, C.; Odobel, F.; Jacquemin, D. Through-space charge transfer in rod-like molecules: Lessons from theory. J. Phys. Chem. C 2012, 116, 11946-11955. [CrossRef]

37. Delley, B. An all-electron numerical method for solving the local density functional for polyatomic molecules. J. Chem. Phys. 1990, 92, 508-517. [CrossRef]

38. Delley, B. From molecules to solids with the DMol3 approach. J. Chem. Phys. 2000, 113, 7756-7764. [CrossRef]

39. Zhang, Z.; Hu, W.; He, R.; Shen, W.; Li, M. The influence of inserted thiophene into the $\left(\pi-\mathrm{A}^{\prime}-\pi\right)$-bridge on photovoltaic performances of dye-sensitized solar cells. Mater. Chem. Phys. 2017, 191, 121-128. [CrossRef]

40. Pastore, M.; De Angelis, F. Computational modelling of $\mathrm{TiO}_{2}$ surfaces sensitized by organic dyes with different anchoring groups: Adsorption modes, electronic structure and implication for electron injection/recombination. Phys. Chem. Chem. Phys. 2012, 14, 920-928. [CrossRef] 
41. Perdew, J.P.; Chevary, J.A.; Vosko, S.H.; Jackson, K.A.; Pederson, M.R.; Singh, D.J.; Fiolhais, C. Atoms, molecules, solids, and surfaces: Applications of the generalized gradient approximation for exchange and correlation. Phys. Rev. B 1992, 46, 6671-6687. [CrossRef]

42. Perdew, J.P.; Burke, K.; Ernzerhof, M. Generalized gradient approximation made simple. Phys. Rev. Lett. 1996, 77, 3865-3868. [CrossRef] [PubMed]

43. Perdew, J.P.; Burke, K.; Ernzerhof, M. Errata. Phys. Rev. Lett. 1997, 78, 1396. [CrossRef]

44. Zhang, J.; Li, H.B.; Sun, S.L.; Geng, Y.; Wu, Y.; Su, Z.M. Density functional theory characterization and design of high-performance diarylamine-fluorene dyes with different $\pi$ spacers for dye-sensitized solar cells. J. Mater. Chem. 2012, 22, 568-576. [CrossRef]

45. Mehmood, U.; Hussein, I.A.; Daud, M.; Ahmed, S.; Harrabi, K. Theoretical study of benzene/thiophene based photosensitizers for dye sensitized solar cells (DSSCs). Dyes Pigm. 2015, 118, 152-158. [CrossRef]

46. Novir, S.B.; Hashemianzadeh, S.M. Density functional theory study of new azo dyes with different $\pi$-spacers for dye-sensitized solar cells. Spectrochim. Acta A Mol. Biomol. Spectrosc. 2015, 143, 20-34. [CrossRef] [PubMed]

47. Xu, Z.; Li, Y.; Zhang, W.; Yuan, S.; Hao, L.; Xu, T. Lu, X. DFT/TD-DFT study of novel T shaped phenothiazine-based organic dyes for dye-sensitized solar cells applications. Spectrochim. Acta A Mol. Biomol. Spectrosc. 2019, 212, 272-280. [CrossRef]

48. Asbury, J.B.; Wang, Y.Q.; Hao, E.; Ghosh, H.N.; Lian, T. Evidences of hot excited state electron injection from sensitizer molecules to $\mathrm{TiO}_{2}$ nanocrystalline thin films. Res. Chem. Intermed. 2001, 27, 393-406. [CrossRef]

49. Pastore, M.; Fantacci, S.; De Angelis, F. Ab initio determination of ground and excited state oxidation potentials of organic chromophores for dye-sensitized solar cells. J. Phys. Chem. C 2010, 114, 22742-22750. [CrossRef]

50. Persson, P.; Lundqvist, M.J.; Ernstorfer, R.; Goddard, W.A.; Willig, F. Quantum chemical calculations of the influence of anchor-cum-spacer groups on femtosecond electron transfer times in dye-sensitized semiconductor nanocrystals. J. Chem. Theory Comput. 2006, 2, 441-451. [CrossRef]

51. Labat, F.; Bahers, T.; Ciofini, I.; Adamo, C. First-principles modeling of dye-sensitized solar cells: Challenges and perspectives. Acc. Chem. Res. 2012, 45, 1268-1277. [CrossRef]

Sample Availability: Samples of the compounds are not available from the authors.

(C) 2020 by the authors. Licensee MDPI, Basel, Switzerland. This article is an open access article distributed under the terms and conditions of the Creative Commons Attribution (CC BY) license (http://creativecommons.org/licenses/by/4.0/). 